\title{
Impact of carbon and nitrogen on bioclogging in a sand grain managed aquifer recharge (MAR)
}

\author{
Heonseop Eom ${ }^{1}$, Sami Flimban ${ }^{1}$ Anup Gurung ${ }^{1}$, Heejun Suk², Yongcheol Kim², Yong Seong Kim³, \\ Sokhee P. Jung ${ }^{4}$, Sang-Eun $\mathrm{Oh}^{{ }^{+}}$ \\ ${ }^{1}$ Department of Biological Environment, Kangwon National University, Chuncheon-si, 200-701, Republic of Korea \\ ${ }^{2}$ Geologic Environment Division, Korea Institute of Geoscience and Mineral Resources, Daejeon 305-350, Republic of Korea \\ ${ }^{3}$ Department of Regional Infrastructure Engineering, Kangwon National University, Republic of Korea \\ ${ }^{4}$ Department of Environment and Energy Engineering, Chonnam National University, Gwangju, Republic of Korea
}

\begin{abstract}
Managed aquifer recharge (MAR), an intentional storage of excess water to an aquifer, is becoming a promising water resource management tool to cope with the worldwide water shortage. Bioclogging is a commonly encountered operational issue that lowers hydraulic conductivity and overall performance in MAR. The current study investigates the impact of carbon and nitrogen in recharge water on bioclogging in MAR For this investigation, continuous-flow columns packed with sand grains were operated with influents having 0 (C1), 5 (C2), and 100 mg/L (C3) of glucose with or without introduction of nitrate. Hydraulic conductivity was analyzed to evaluate bioclogging in the systems. In $\mathrm{C} 1$ and $\mathrm{C} 2$, hydraulic conductivity was not significantly changed overall. However, hydraulic conductivity in C3 was decreased by $28.5 \%$ after three weeks of operation, which appears to be attributed to generation of fermentation bacteria. Introduction of nitrogen to C3 led to a further decrease in hydraulic conductivity by $25.7 \%$ compared to before it was added, most likely due to stimulation of denitrifying bacteria. These findings indicate that high carbon contents and introduction of additional nitrogen in recharge water cause serious bioclogging in MAR, suggesting the necessity for controlling quality of recharge water.
\end{abstract}

Keywords: Bioclogging, Carbon, Hydraulic conductivity, Managed aquifer recharge, Nitrogen

\section{Introduction}

Global access of freshwater resources on earth is approaching the limits of sustainability due to less constant water supply and increasing global population [1-4]. Thus, water reclamation and appropriate reuse has become a critical issue world-wide [2]. Recently, managed aquifer recharge (MAR), the purposeful recharge of water to an aquifer, is receiving great attention as a vital management tool in the sustainable use of the world's water resources [5-8]. MAR provides safe storage of water from a variety of sources, including stream, stormwater runoff, municipal or industrial wastewater, and irrigation flow, against evaporation and secondary contamination in times of water surplus to meet demand in times of shortage [5, 9-11]. Moreover, the MAR potentially improves the quality of water via physical and biogeochemical processes during infiltration and subsurface transport, and it can also act as a barrier to prevent saline instruction [12-15]. MAR takes on various forms depending on the sources of recharge water, infiltration techniques, end use of recovered water, and scale and complexity, with aquifer storage and recovery (ASR) and infiltration basin type being the most common [6, 16, 17].

Clogging is commonly encountered in MAR [2, 18-20]. This can result from natural physicochemical processes caused by filtration of suspended solids in recharge water [2, 21] or biological reactions in porous soil media caused by bacterial cell accumulation and extracellular polysaccharide production [2, 19, 22]. While microbially-induced clogging, termed bioclogging, may increase the efficiency of natural filtration as retention time increases [23], it is generally problematic in MAR by decreasing the porosity and hydraulic conductivity of a saturated porous medium and limiting the capacity of the MAR [24-28]. Therefore, understanding microbial
This is an Open Access article distributed under the terms of the Creative Commons Attribution Non-Commercial License (http://creativecommons.org/licenses/by-nc/3.0/) which permits unrestricted non-commercial use, distribution, and reproduction in any medium, provided the original work is properly cited.
Received September 06, 2019 Accepted November 03, 2019

${ }^{\dagger}$ Corresponding author

Email: ohsangeun@kangwon.ac.kr

Tel: +82-33-243-6449 Fax: +82-33-242-6450

Copyright (C) 2020 Korean Society of Environmental Engineers 
stimulation and factors affecting it in MAR could lead to better operation and efficiency of the MAR.

There are earlier studies reported microbially-induced clogging in porous media [29-31]. They focused mainly on the influences of growth, thickness, transport, and morphology of biofilm on hydraulic conductivity in porous media [29-31]. However, despite the fact that nutrients such as carbon and nitrogen in recharge water can be utilized for microbial growth and can thereby contribute to bioclogging in the MAR, their effects on hydraulic conductivity are not fully understood.

The current study evaluated the impacts of nutrients in recharge water on bioclogging in a sand grain MAR. In particular, we investigated microbial stimulation in a MAR by high contents of carbon and nitrogen in recharge water. For this study, we operated a continuous-flow permeameter packed with sand grains and analyzed changes in hydraulic conductivity depending on the quantity of glucose and additional introduction of nitrogen in recharge water. Based on the findings from the present study, we discuss the contributions of the quality of recharge water to bioclogging in the MAR.

\section{Materials and Methods}

\subsection{Configuration and Operational Conditions of the Continuous-Flow Columns}

The configuration of the constant-head permeameter is shown in Fig. 1. Experiments were conducted in three cylindrical acrylic columns with $10 \mathrm{~cm}$ lengths and $7 \mathrm{~cm}$ diameters. The columns were packed with 0.07-0.87 mm diameter graded Ottawa sand (silica classified \#C109 ASTM \#C778), supported by stainless steel mesh placed inside the column end caps. Tap water was used as the source of influent; it was dechlorinated by adding granular activated carbon (200 mg/L) and sparging with air for $2 \mathrm{~h}$ prior to use. After dechlorination, tap water was again sparging with nitrogen gas to remove dissolved oxygen (DO) for simulating conditions of low dissolved oxygen in groundwater. Characteristics of tap water were as follows: $6.7 \pm 0.02$ of $\mathrm{pH}, 217 \pm 6.1 \mu \mathrm{S} / \mathrm{cm}$ of electrical conductivity (EC), $0.1 \pm 0.05$ of $\mathrm{DO}, 0.17 \pm 0.06$ of total nitrogen, and $0.6 \pm 0.08$ NTU of turbidity. Local soil provided the inoculum in the columns. Approximately $100 \mathrm{~g}$ of soil was collected from the premises of Kangwon National University, Chuncheon, Korea and mixed with $300 \mathrm{~mL}$ of tap water to simulate microbial growth in a natural soil environment. The mixture was shaken for 10-15 min in an incubator at $150 \mathrm{rpm}\left(30^{\circ} \mathrm{C}\right)$ and $0.5 \mathrm{~mL}$ of supernatant was added as inoculum to each column.

Three columns (C1, C2 and C3) were operated under water-saturated conditions at constant room temperature. Using an adjustable peristaltic pump, the influent was fed at a flow rate of $0.94 \mathrm{~mL} / \mathrm{min}$, which approximates the flow of velocity of typical groundwater in sandy aquifers [28]. Empty bed contact time for all columns was calculated to be $57.7 \mathrm{~h}$. The contents of glucose and nitrate in the influents for C1, C2, and C3 during the experiments are summarized in Table 1. Column 1 (C1) was fed with tap water alone as a control. Columns 2 (C2) and 3 (C3) were fed with 5 $\mathrm{mg} / \mathrm{L}$ and $100 \mathrm{mg} / \mathrm{L}$ of glucose, respectively, which simulate recharge water that contains relatively low and high contents of nutrients. Until day 84, all columns were operated with glucose only and then $20 \mathrm{mg} \mathrm{N} / \mathrm{L}$ of nitrate was introduced until the end of operations (day 112). All influents were refreshed every $2 \mathrm{~d}$ to prevent degradation of glucose before they were applied to the sand grain columns. All experiments were performed in triplicate and the average values are reported in the results.

Table 1. Operational Conditions of Continuous-flow Columns

\begin{tabular}{lccccc}
\hline Column & \multicolumn{2}{c}{ Day } & $\mathbf{0 - 8 4}$ & & \multicolumn{2}{c}{ Day } & $\mathbf{8 5 - 1 1 8}$ \\
\cline { 2 - 3 } \cline { 5 - 6 } & $\begin{array}{c}\text { Glucose } \\
(\mathbf{m g} / \mathbf{L})\end{array}$ & $\begin{array}{c}\text { Nitrate } \\
(\mathbf{m g} \mathbf{~ N} / \mathbf{L})\end{array}$ & & $\begin{array}{c}\text { Glucose } \\
(\mathbf{m g} / \mathbf{L})\end{array}$ & $\begin{array}{c}\text { Nitrate } \\
(\mathbf{m g ~ N} / \mathbf{L})\end{array}$ \\
\hline C1 & 0 & 0 & 0 & 20 \\
C2 & 5 & 0 & 5 & 20 \\
C3 & 100 & 0 & 100 & 20 \\
\hline
\end{tabular}
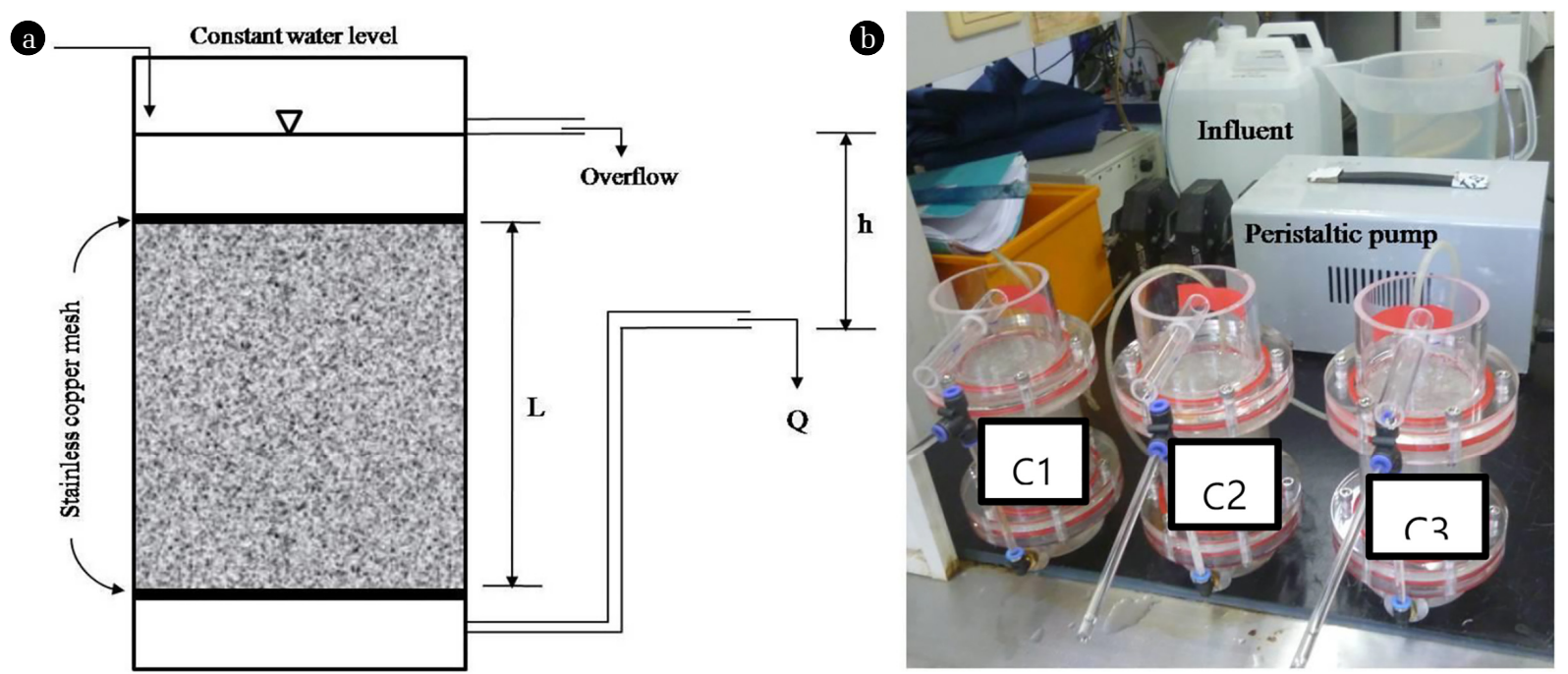

Fig. 1. Schematic diagram (a) and a picture of continuous-flow columns (b). The values for $L$, $h$, and $Q$ are $10 \mathrm{~cm}, 7 \mathrm{~cm}$, and $0.94 \mathrm{~mL} / \mathrm{min}$, respectively. 


\subsection{Measurement of Hydraulic Conductivity}

Hydraulic conductivity (K;cm/s) was analyzed based on Darcy's Law (1) on days $1,21,42,63,86,105$, and 118 :

$$
\mathrm{K}=\mathrm{QL} / \mathrm{hAt}
$$

where Q represents the rate of flow or volume of water per unit time $\left(\mathrm{cm}^{3} / \mathrm{s}\right), \mathrm{L}$ is the length of the sand column $(\mathrm{cm}), \mathrm{h}$ is the constant head difference $(\mathrm{cm})$, A represents the cross-sectional area $\left(\mathrm{cm}^{2}\right)$ and $\mathrm{t}$ denotes time $(\mathrm{s})$.

\subsection{Biochemical Analysis}

For chemical analyses, $50 \mathrm{~mL}$ of sample was collected from the influent and effluent ports of each column on day 1, 21, 42, 63, 86, 105, and 118, and chemical oxygen demand (COD), glucose, and nitrate (only on day 86, 105, and 118) were measured. COD was determined based on standard methods for water and wastewater [32]. Glucose concentrations were analyzed using the phenol-sulfuric method [33]. For nitrate analysis, approximately 20 $\mathrm{mL}$ of sample was passed through a $0.45 \mu \mathrm{m}$ syringe filter (Smart Pore; Woongki Science Co. Ltd., South Korea) and stored at $4^{\circ} \mathrm{C}$ prior to ion chromatography analysis (DX-100, AS14 column; Dionex Corp, USA). The numbers of bacteria were measured by cell counting using a Neubauer chamber on days 21, 84, and 118.

\subsection{Statistical Analysis}

All data were analyzed using Microsoft Excel 2016 and graphed using Microsoft Excel 2016 and Sigma Plot 10. To evaluate the statistical significance of the results, p-values were analyzed based on the t-test using the method in a study of Welch [34].

\section{Results and Discussion}

K values obtained during the bioclogging test in columns packed with sand grains under continuous-flow condition are illustrated in Fig. 2. The $\mathrm{K}$ values in C1 ( $0 \mathrm{mg} / \mathrm{L}$ of glucose) and C2 (5 mg/L of glucose) did not show significant changes overall. On the contrary, the $\mathrm{K}$ values in C3 (100 mg/L of glucose) were substantially changed by time and the introduction of nitrate. Effects of carbon (glucose) and nitrogen (nitrate) on hydraulic conductivity are discussed in detail below.

\subsection{Impact of Glucose on Hydraulic Conductivity}

The effect of glucose on bioclogging was evaluated based on the $\mathrm{K}$ values during operations of C1, C2, and C3 with no introduction of nitrate. The $\mathrm{K}$ values in $\mathrm{C} 1$ were statistically constant ( $\mathrm{p}$-value $<0.05)$ until day 63 with an average value of $0.0227 \pm 2.16$ $\times 10^{-4} \mathrm{~cm} / \mathrm{s}$. While overall $\mathrm{K}$ values in C2 (on average, 0.0221 $\pm 3.45 \times 10^{-4} \mathrm{~cm} / \mathrm{s}$ ) were slightly smaller than those in $\mathrm{C} 1$, they also remained statistically unchanged (p-value $<0.05$ ) until day 63. However, the $\mathrm{K}$ values in $\mathrm{C} 3$ significantly decreased from $0.0235 \pm 2.52 \times 10^{-4} \mathrm{~cm} / \mathrm{S}$ to $0.0168 \pm 4.16 \times 10^{-4} \mathrm{~cm} / \mathrm{s}$ during the first 21 days and then they were not notably changed until day 63. This change in the $\mathrm{K}$ values in $\mathrm{C} 3$ corresponds to the earlier reports about bioclogging [35-39]. For example, Jeong et al [39] likewise reported that hydraulic conductivity sharply decreased

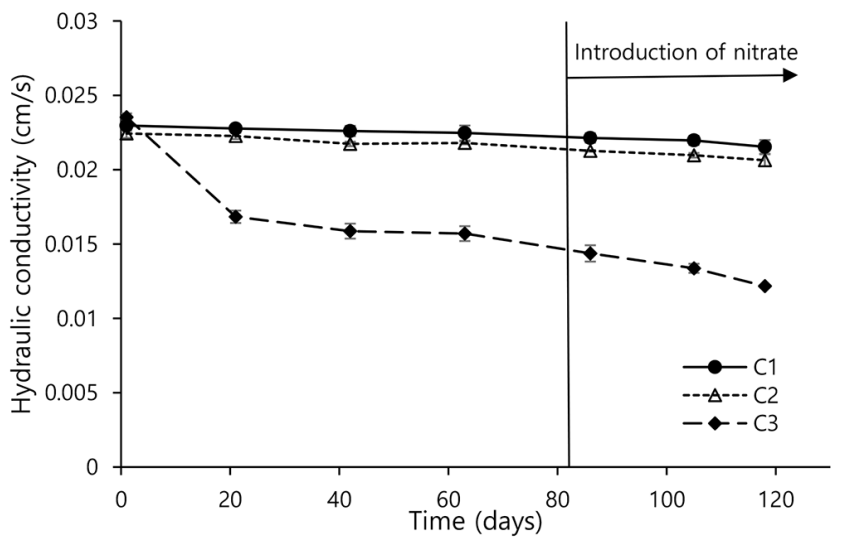

Fig. 2. Changes of hydraulic conductivity in continuous-flow columns. Error bars represent the standard deviations from triplicate experiments.

early in the operation of a sandy column under continuous flow and then no further significant drop in hydraulic conductivity was discovered. They considered that in the early stages of bioclogging, aerobic and anerobic microorganisms multiplied rapidly to form colonies and occupied the pore channel, causing blocking water flow and a sharp decrease in hydrodynamic dispersion. However, when microbial colonies developed to a certain level, water flow transformed from uniform to non-uniform flow, resulting in no more significant decrease in hydraulic conductivity.

The data from bacteria counting (Fig. 3) confirms that the variation in hydraulic conductivity between C2 and C3 was mainly attributed to microorganism stimulation in sand grains. Bacterial counts in C1 and C2 at day 21 accounted for $1.43 \times 10^{4} \pm 1404$ and $1.57 \times 10^{4} \pm 1501$ cells $/ \mathrm{mL}$, respectively; whereas the value for C3 was considerably higher, $5.97 \times 10^{4} \pm 3113$ cells $/ \mathrm{mL}$. It is speculated that this greater microbial stimulation in C3 is associated with fermentation. As Fig. 4 demonstrates, C3 showed a significant glucose removal (approximately 40\%); however, no COD removal was observed in C3. Moreover, while C1 and C2 commonly

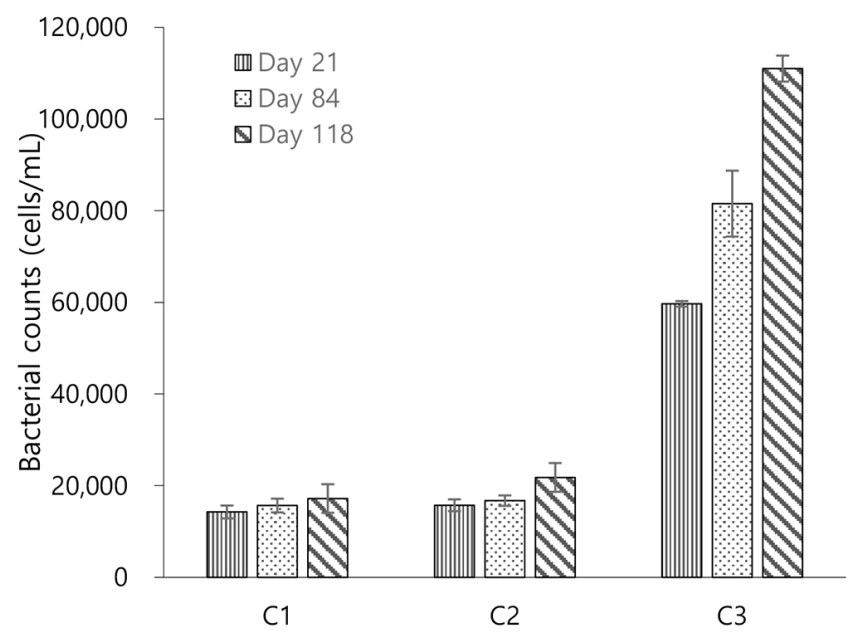

Fig. 3. Bacterial counts in sand grains of continuous-flow columns. Error bars represent the standard deviations from triplicate experiments. 

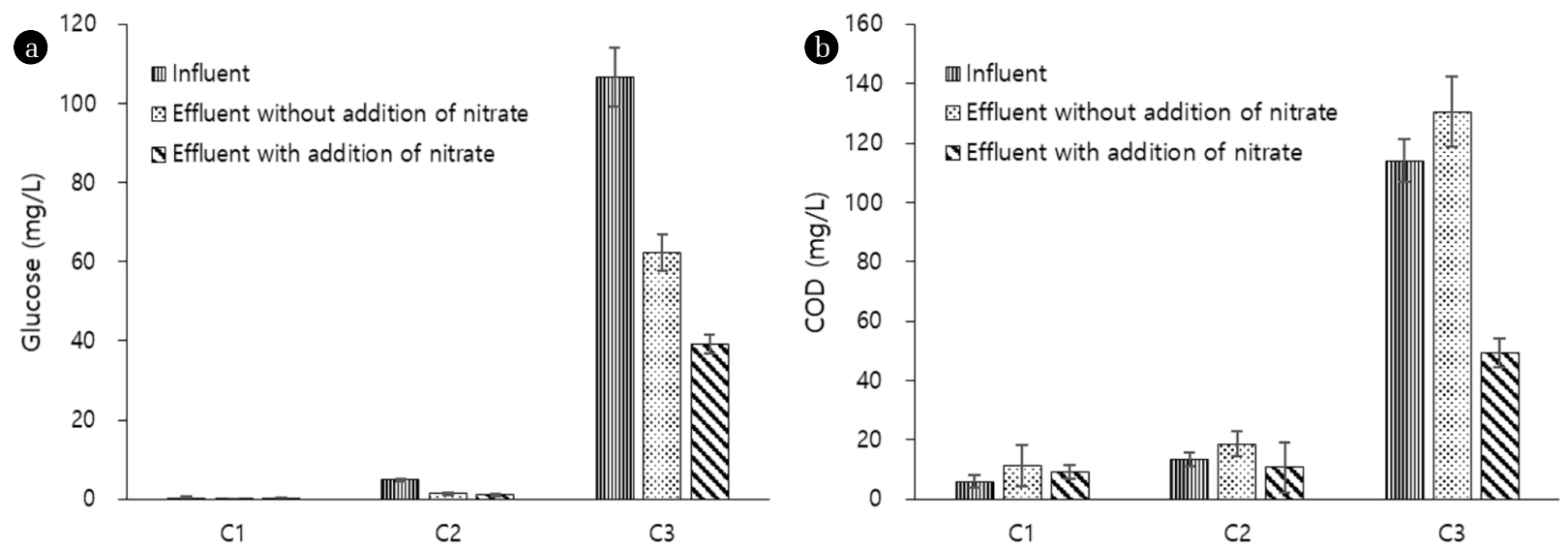

Fig. 4. (a) Average concentrations of glucose and (b) COD in influents and effluents of continuous-flow columns. Error bars represent the standard deviations. The number of sample collection for data of influent, effluent without addition of nitrate, and effluent with addition of nitrate were 7,4 , and 3 , respectively.

showed fairly similar $\mathrm{pH}$ values between influents (on average, 6.5 \pm 0.2 in $\mathrm{C} 1$ and $6.7 \pm 0.1$ in C2) and effluents (on average, 6.6 \pm 0.2 in $\mathrm{C} 1$ and $6.5 \pm 0.1$ in C2), only C3 presented a substantial drop in $\mathrm{pH}$ between influents (on average, $6.6 \pm 0.1$ ) and effluents (on average, $3.1 \pm 0.3$ ). Given that electron acceptors such as dissolved oxygen and nitrate rarely exist in the sand grains, these results suggest that fermentation was the main cause for glucose removal and fermentation by-products such as organic acids and alcohols attributed to the no COD removal and decrease in $\mathrm{pH}$ in C3.

The above results of the $\mathrm{K}$ values in $\mathrm{C} 1, \mathrm{C} 2$, and $\mathrm{C} 3$ until day 63 indicate that the content of glucose highly impacts hydraulic properties by stimulating microorganisms. When recharge water contains low carbon concentration (C2), hydraulic conductivity was not substantially worsened. On the other hand, recharge water that possesses high carbon content (C3) leads to a significant decrease in hydraulic conductivity in the system. This observance suggests that control for organic matter in recharge water is necessary for sustainable operation of MAR.

\subsection{Impact of Nitrate on Hydraulic Conductivity}

Hydraulic conductivity in C1, C2, and C3 before and after introduction of nitrate is compared to investigate the effect of nitrogen on bioclogging. In $\mathrm{C} 1$ and $\mathrm{C} 2$, slight decreases in $\mathrm{K}$ values were observed after introduction of nitrate, on average, from $0.0228 \pm$ $2.16 \times 10^{-4} \mathrm{~cm} / \mathrm{s}$ to $0.0218 \pm 3.09 \times 10^{-4} \mathrm{~cm} / \mathrm{s}$ and from 0.0221 $\pm 3.44 \times 10^{-4} \mathrm{~cm} / \mathrm{s}$ to $0.0209 \pm 3.16 \times 10^{-4} \mathrm{~cm} / \mathrm{s}$, respectively (Fig. 2). Results of bacterial counts before and after introduction of nitrate in C1 and C2 were also minimally changed (Fig. 3). For example, before nitrate was introduced, the average bacterial counts in C1 and C2 accounted for $1.43 \times 10^{4} \pm 1404$ and 1.57 $\times 10^{4} \pm 1501$ cells/L at day 21 , respectively, which slightly increased to $1.57 \times 10^{4} \pm 1285$ and $1.67 \times 10^{4} \pm 1137$ cells/L at day 84 , respectively, with introduction of nitrate.

Unlike in $\mathrm{C} 1$ and $\mathrm{C} 2$, the $\mathrm{K}$ values in $\mathrm{C} 3$ before and after introduction of nitrate were fairly varied. Before introduction of nitrate, the average $\mathrm{K}$ value in C3 was $0.0179 \pm 3.73 \times 10^{-3} \mathrm{~cm} / \mathrm{s}$, which decreased to $0.0133 \pm 1.11 \times 10^{-3} \mathrm{~cm} / \mathrm{s}$ after introduction of nitrate (Fig. 2).
Data of bacterial counts in C3 supports that this decline is attributed to microbial reproduction. Before nitrate was introduced, the result of bacterial counts in $\mathrm{C} 3$ was $5.97 \times 10^{4} \pm 3113 \mathrm{cells} / \mathrm{mL}$ at day 21; with introduction of nitrate, this value increased to $8.15 \times 10^{5}$ \pm 3139 cells $/ \mathrm{mL}$ at day 84 (Fig. 3). It appears that this increase in bacterial counts is relevant to stimulation of denitrifying bacteria that utilizes nitrogen as an electron acceptor. Fig. 4 presents that introduction of nitrate led to COD removal 57\% in C3, which did not occur before nitrate was introduced. Furthermore, a decrease in $\mathrm{pH}$ between influents (on average, $6.6 \pm 0.1$ ) and effluents (on average, $6.4 \pm 0.2$ ) was no longer observed in C3 with introduction of nitrate. These results suggest that fermentation did not occur after nitrate was introduced. This is most likely because the introduced nitrate served as an electron acceptor. In addition, the finding that $44 \%$ of the introduced nitrate was removed only in C3 (Fig. 5) also supports that denitrifying bacteria were stimulated.

The findings from the above analyses demonstrate that nitrogen can be a factor affecting bioclogging in MAR. While introduction

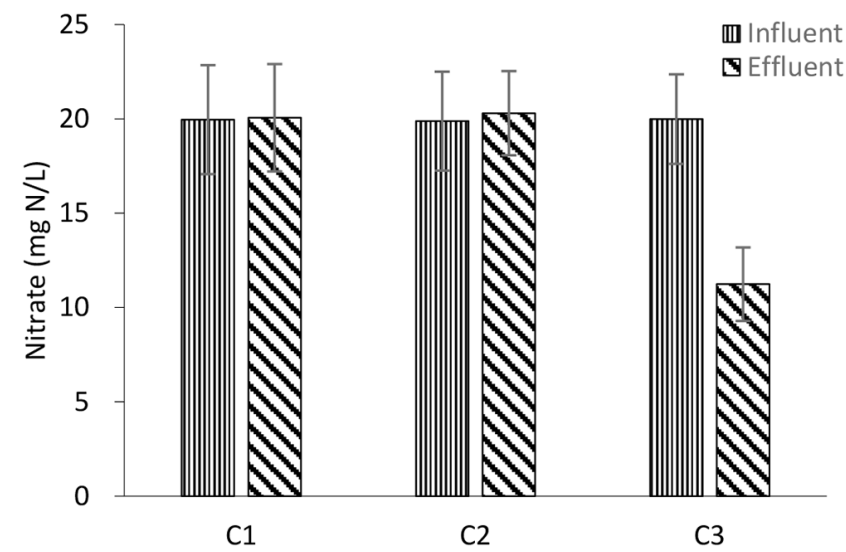

Fig. 5. Average concentrations of nitrate in influents and effluents of continuous-flow columns. Error bars represent the standard deviations. The number of samples were 3 in both influents and effluents. 
of nitrate was not able to stimulate significant microbial growth under conditions of insufficient organic content, nitrate boosts microbial reproduction, particularly that of denitrifying bacteria, when sufficient organic matter is provided. This suggests that control of both electron donors (i.e., organic matter) and acceptors (i.e., nitrogen) in recharge water can provide a more effective measure for avoiding excessive bioclogging in the MAR.

\subsection{Quality of Recharge Water and Its Impact on Bioclogging in MAR}

The current study investigated effects of nutrients in recharge water on bioclogging in a sand grain MAR. The results demonstrate that high contents of carbon and additional introduction of nitrogen resulted in significant stimulation of fermentation and denitrifying bacteria, leading to serious bioclogging in a sand grain MAR. As discussed in the introduction, sources for recharge water include not only highly treated water such as effluents from water treatment facilities but also less or none treated water including stormwater runoff and irrigation flow. The present study demonstrates that employment of untreated water to MAR can adversely affect sustainability of MAR. However, reliable guidelines for quality of recharge water to prevent bioclogging in MAR have not been developed yet. Most earlier attempts have been based on limited research data [40], and others have recommended treating recharge water to a level of drinking water quality [5]. Given that most MAR operations utilize reclaimed water, achieving such costly high-quality recharge water may be inefficient. Hence, further evaluation for relations between various water quality parameters and bioclogging in MAR systems is necessary, which will aid in developing efficient guidelines for sustainable operation of MAR.

\section{Conclusions}

The effects of glucose and additional nitrate introduction on bioclogging to continuous-flow columns packed with sand grains were evaluated based on hydraulic conductivity ( $\mathrm{K}$ value). In $\mathrm{C} 1$ and $\mathrm{C} 2$, having influents with 0 and $5 \mathrm{mg} / \mathrm{L}$ of glucose, respectively, hydraulic conductivity was relatively unchanged during overall experiments. However, in C3, having influents with $100 \mathrm{mg} / \mathrm{L}$ of glucose, hydraulic conductivity decreased by $28.5 \%$ in the first three weeks, which was associated with growth of fermentation bacteria. Moreover, introduction of nitrate to C3 caused a further decrease in hydraulic conductivity by $25.7 \%$, which is possibly attributed to reproduction of denitrifying bacteria. These results show that nutrients in recharge water are factors affecting bioclogging in MAR, suggesting that it is necessary to control the quality of recharge water for better and sustainable operation of MAR.

\section{Acknowledgments}

This work was supported by the Korea Ministry of Environment (The SEM project: 2018002450001) and partially supported by
2017 Research Grant from Kangwon National University.

\section{Author Contributions}

H.E. (Post-doctoral researcher) planned the study and wrote the manuscript. S.F. (Post-doctoral researcher) and A.G. (Post-doctoral researcher) conducted experiments. H.S. (Senior researcher), Y.K.. (Senior researcher), Y.S.K. (Professor), and S.P.J. (Professor) performed data analysis. S.-E.O. (Professor) planned the study and revised the manuscript.

\section{References}

1. Stikker A. Water today and tomorrow: prospects for overcoming scarcity. Futures 1998;30:43-62.

2. Rinck-Pfeiffer S, Ragusa S, Sztajnbok P, et al. Interrelationships between biological, chemical, and physical processes as an analog to clogging in aquifer storage and recovery (ASR) wells. Water Res. 2000;34:2110-2118.

3. Kivaisi AK. The potential for constructed wetlands for wastewater treatment and reuse in developing countries: A review. Ecol. Eng. 2001:16:545-560.

4. Bruch I, Fritsche J, Bänninger D, et al. Improving the treatment efficiency of constructed wetlands with zeolite-containing filter sands. Bioresour. Technol. 2011;102:937-941.

5. Bouwer H. Artificial recharge of groundwater: hydrogeology and engineering. Hydrogeol. J. 2002;10:121-142.

6. Dillon P. Future management of aquifer recharge. Hydrogeol. J. 2005;13:313-316.

7. Bouwer H, Pyne R, Brown J, et al. Design, operation, and maintenance for sustainable underground storage facilities. Denver: AWWA Research Foundation; 2008. p. 1-5.

8. Page D, Bekele E, Vanderzalm J, et al. 2018 Managed aquifer recharge (MAR) in sustinable urban water management. Water 2018;10:239.

9. Ma L, Spalding RF. Effects of artificial recharge on ground water quality and aquifer storage recovery. J. Am. Water Resour. Assoc. 1997;33:561-572.

10. Drewes JE. Ground water replenishment with recycled water quality improvements during managed aquifer recharge. Ground Water 2009;47:502-505.

11. Page D, Miotlinski K, Dillon P, et al. Water quality requirements for sustaining aquifer storage and recovery operations in low permeability fractured rock aquifer. J. Environ. Manage. 2011;92:2410-2418.

12. Fox P, Houston S, Westerhoff P. Advances in Soil Aquifer Treatment Research for Sustainable Water Reuse. Denver: AWWA Research Foundation; 2006. p. 70-72.

13. Shammas M. The effectiveness of artificial recharge in combating seawater intrusion in Salalah coastal aquifer, Oman. Environ. Geology 2008;55:191-204.

14. Daher W, Pistre S, Kneppers, et al. Karst and artificial recharge: Theoretical and practical problems: A preliminary approach to artificial recharge assessment. J. Hydrol. 2011;408:189-202. 15. Schmidt CM, Fisher AT, Racz AJ, et al. Linking denitrification 
and infiltration rates during managed groundwater recharge. Environ. Sci. Techol. 2011;45:9634-9640.

16. Kimrey JO. Artificial recharge of groundwater and its role in water management. Desalination 1989;72:135-147.

17. Smith L. Clogging mechanisms in managed aquifer recharge: a case study at Mining Area C [thesis]. Perth: The University of Western Australia; 2014.

18. Alfredo P. Integrated modelling of clogging processes in artificial groundwater recharge [dissertation]. Barcelona: Technical University of Catalonia; 2000.

19. Pavelic P, Dillon PJ, Barry, KE, et al. Water quality effects on clogging rates during reclaimed water ASR in a carbonate aquifer. J. Hydrol. 2007;334:1-16.

20. Kim J-W, Choi H, Pachepsky YA. Biofilm morphology as related to the porous media clogging. Water Res, 2010;44:1193-1201.

21. Pavelic P, Dillon Pj, Barry KE, et al. Well clogging effects determined from mass balances and hydraulic response at a stormwater ASR site. In: Proceedings of the Third International Sympsium on Artificial Recharge of Groundwater; 21-25 September 1998; Amsterdam. p. 61-66.

22. Pell M, Nyberg F. Infiltration of Wastewater in a Newly Started Pilot Sand-Filter System: II. Development and Distribution of the Bacterial Populations. J. Environ. Qual. 1989;18:457-462.

23. Van Cuyk S, Siegrist R, Logan A, et al. Hydraulic and purification behaviors and their interactions during wastewater treatment in soil infiltration systems. Water Res. 2001;35:953-964.

24. Taylor SW, Milly PCD, Jaffé PR. Biofilm growth and the related changes in the physical properties of a porous medium: 2 . Permeability. Water Resour. Res. 1990;26:2161-2169.

25. Clement TP, Hooker BS, Skeen RS. Macroscopic Models for Predicting Changes in Saturated Porous Media Properties Caused by Microbial Growth. Ground Water 1996;34:934-942.

26. Baveye P, Vandevivere P, Hoyle BL, et al. Environmental impact and mechanisms of the biological clogging of saturated soils and aquifer materials. Crit. Rev. Environ. Sci. Techol. 1998;28:123-191.

27. Soleimani S, Van Geel PJ, Isgor OB, et al. Modeling of biological clogging in unsaturated porous media. J. Contam. Hydrol. 2009;106:39-50.

28. Seifert D, Engesgaard P. Sand box experiments with bioclogging of porous media: Hydraulic conductivity reductions. J. Contam. Hydrol. 2012;136-137:1-9.

29. Cunningham AB, Characklis WG, Abedeen F, et al. Influence of biofilm accumulation on porous-media hydrodynamics. Environ. Sci. Technol. 1991;25,1305-1311.

30. Wu J, Gui, S, Stahl P, Zhang R. Experimental study on the reduction of soil hydraulic conductivity by enhanced biomass growth. Soil Sci. 1997;162:741-748.

31. Stoodley P, Dodds I, De Beer D, et al. Flowing biofilms as a transport mechanism for biomass through porous media under laminar and turbulent conditions in a laboratory reactor system. Biofouling 2005;21:161-168.

32. APHA. Standards Methods for the examination of water and wastewater. 20th ed. Washington DC: American Public Health Association; 1998. p. 5.14-5.19.

33. DuBois M, Gilles KA, Hamilton JK, et al. 1956 Colorimetric Method for Determination of Sugars and Related Substances. Anal. Chem. 1956;28:350-356.

34. Welch BL. The generalization of 'Student's' problem when several different population variances are involved. Biometrika 1947;34:28-35.

35. Engesgaard P, Seifert D, Herrera P. Bioclogging in porous media: Tracer studies. In: Riverbank Filtration Hydrology - Impacts on System Capacity and Water Quality. Hubbs SA, eds., NATO Sci. Ser. IV Earth Environ. Sci. Dordrecht: Springer; 2006. p. 155-178.

36. Flemming HC, Wingender J. The biofilm matrix. Nat. Rev. Microbiol. 2010;8:623-633.

37. Physics of bacterial near-surface motility using flagella and type IV pili: implications for biofilm formation. Microbio. Res. 2012;163:619-629.

38. Zhong $\mathrm{X}, \mathrm{Wu}$ Y. Bioclogging in porous media under continous-flow condition. Eviron. Earth Sci. 2013;68:2417-2425.

39. Jeong HY, Jun SC, Cheon JY, et al. A review on clogging mechanisms and managements in aquifer storage and recovery (ASR) applications. Geosci. J. 2018;22:667-679.

40. Pe'rez-Paricio A, Carrera J. EU Project on Artificial Recharge of Groundwater, Research Program on Environment and Climate. 1999; Contract ENV-CT95-0071, European Commonwealth, Brussels. 